\title{
Occurrence of physiological browning disorders in stored 'Braeburn' apples as influenced by orchard and weather conditions
}

\author{
R.J. McCormick ${ }^{\mathrm{a} 1}, \mathrm{~K}$. Biegert ${ }^{2}$ and J. Streif ${ }^{3}$ \\ Kompetenzzentrum Obstbau Bodensee, Ravensburg, Germany. \\ ${ }^{1}$ mccormick@kob-bavendorf.de ${ }^{2}$ konni.biegert@kob-bavendorf.de ${ }^{3}$ streif@kob-bavendorf.de
}

\begin{abstract}
Physiological storage disorders continue to cause sizable economic losses in a range of commercially important pomefruit cultivars. Given similar storage regimes, the incidence and severity of browning disorders in the apple cultivar 'Braeburn' can vary in different years in a way that can be explained by the interaction of preharvest seasonal and orchard factors. Over a three-year period (2016 to 2019) at the Kompetenzzentrum Obstbau-Bodensee (KOB) in Southwest Germany a range of orchard and storage treatments were conducted for: air temperature during cell division for three weeks post petalfall or during four weeks preharvest, calcium orchard sprays, crop load and harvest timings. Following controlled atmosphere (CA) storage, the disorder incidence for internal browning and cavity formation varied markedly over the three different growing seasons. Crop load treatments strongly influenced the expression of browning disorders in all years. Differences in air temperatures $\left(\triangle+/-2{ }^{\circ} \mathrm{C}\right.$ compared to ambient) during the cell division period showed little effect on browning incidence. Warm night temperatures $\left(>10^{\circ} \mathrm{C}\right)$ prior to harvest can reduce internal browning in 'Braeburn' apples during $\mathrm{CA}$ storage and shelf-life.
\end{abstract}

Keywords: controlled atmosphere (CA) storage, crop load, internal browning disorders, receiver operating characteristic $(\mathrm{ROC})$

\section{INTRODUCTION}

Physiological browning disorders in the apple cultivar 'Braeburn' can occur in the orchard but mostly symptoms develop during postharvest handling and controlled atmosphere (CA) storage. Much of the variation in the occurrence of internal browning symptoms is due to preharvest factors as similar fruit handling and storage conditions often result in very different outcomes (Lau 1998; Elgar et al., 1999; Watkins and Mattheis, 2019).

A conceptual understanding of browning development in 'Braeburn' is supported by recent work to identify genetic biomarkers (Mellidou et al., 2014; Rudell et al., 2017) and technological advances with the non-destructive 3D microstructural analysis of whole fruit (Janssen et al., 2020). The genetic findings link changes in energy and lipid related genes with the spatial and temporal development of browning symptoms in fruit tissues. Furthermore, 'Braeburn' is an apple cultivar with a high resistance to gas exchange, the fruit skin has a low permeance for $\mathrm{O}_{2}$ (Rajapakse et al., 1990) and the cellular microstructure is dense with narrow connecting pores especially within the inner cortex / core tissues (Drazeta et al., 2004; Herremans et al 2013; Janssen et al., 2020). Taken together these research findings are consistent with a model of browning development where failures in the functioning and/or structure of cell membranes occur when respiration processes either do not provide enough energy to maintain cellular defences / homeostasis or products such as $\mathrm{CO}_{2}$ accumulate to damage cells. When cell integrity is lost, cell contents mix, enzymatic oxidation browning occurs, cells can die and cavities can form when cell fluids are lost to surrounding tissues (Herremans et al., 2014). Variation in the cellular microstructure can explain the pattern of browning symptoms. Browning develops in 'hotspots' that often stay localised when surrounding tissues allow for better gas exchange (Herremans et al., 2014).

\footnotetext{
a Corresponding Author: mccormick@kob-bavendorf.de
} 
The management strategy of delayed-CA storage is very effective at controlling browning disorders in 'Braeburn'. Fruit have a higher energy status after a three week period in air storage and begin to better tolerate low temperature CA conditions (Saquet et al., 2003). In addition, apples in air storage can show increases in intercellular volume (Ruess and Stösser, 1993) and these changes could also help fruit adapt to CA conditions by increasing gas exchange within the cortex and core tissues.

Nevertheless, many questions remain about how environmental and orchard factors affect fruit during growth and development on the tree to influence the susceptibility and expression of browning disorders during postharvest handling and storage. Approaches to predict 'Braeburn' browning disorder risk have often included air temperature data, e.g. growing degree day (GDD) models as a number of workers have identified cool growing seasons as a higher risk for browning (Lau, 1998; Volz et al., 2000); with some data to suggest that low temperatures in the $30 \mathrm{~d}$ preharvest period are correlated with a higher browning risk (Volz et al., 2000).

Fruit growth is affected by orchard temperature. Air temperatures during the spring post bloom period (primarily involving cell division in the young fruitlets) and in the autumn preharvest harvest period (fruit maturation and ripening) are known to influence fruit growth and development in a different way compared to temperatures during the summer. Air temperatures in the post bloom and preharvest periods can affect the potential fruit size and the rate of fruit maturation (Warrington et al., 1999) and the incidence of internal browning in 'Braeburn' (Volz et al., 2000).

Light crop loads are a well-known risk factor for a range of postharvest disorders including internal browning in 'Braeburn' however, there is very little literature to understand the physiological basis on how crop load affects final fruit quality following postharvest storage (Ferguson et al., 1999; Wünsche and Ferguson, 2005). Calcium spray treatments in the orchard strongly affect the incidence of bitter pit. However, the effects on 'Braeburn' browning susceptibility are reported as protective (Rabus and Streif, 2000) or less well correlated (Elgar et al., 1999). Furthermore, while late harvests are generally associated with a higher risk of browning susceptibility this is not always the case (Lau, 1998).

From 2016 to 2019, a research project to encourage the use of digital technologies in the horticultural sector was undertaken at the Kompetenzzentrum Obstbau-Bodensee (KOB) in Southwest Germany. The project focused on the prediction of storage disorder risk using a data based classification methodology (Osinenko et al., 2021). The experimental design enabled the linkage between a number of preharvest physiological processes and the occurrence of internal browning disorders during storage to be investigated. Specifically, the following hypotheses were tested: 1) Warm conditions during the three week post-bloom cell division period will predispose 'Braeburn' apples to postharvest internal browning; 2) Warm conditions during the four week pre-harvest period will reduce postharvest internal browning; 3) High crop loads will reduce postharvest browning incidence/severity when preharvest air temperatures in the orchard vary.

\section{MATERIALS AND METHODS}

\subsection{Orchard treatments}

Field experiments involving orchard day/night temperatures, calcium spraying, crop load and harvest date treatments were conducted at the KOB (Table 1). Treatments involved either two or three levels and were replicated three or four times in a randomised design using seven trees per plot. Experiments in all years used the same block of 'Braeburn' apple trees at the $\mathrm{KOB}$ (planted in 2006, 3.2 by $0.8 \mathrm{~m}$ spacing, $3.8 \mathrm{~m}$ in height). Tree canopies were divided into three sectors; top (1/3), middle (1/3) and bottom (1/3) to obtain data on the disorder incidence with regard to fruit position within the tree canopy.

All apples from a specific tree-sector and storage condition represented one storage sample (Table 1). Each sample was harvested, stored and assessed separately excluding 2016, here trees were harvested as total apples per sector within a repetition (Table 1). 
Table 1. Overview of the field and storage experiments* conducted on 'Braeburn' trees at the Kompetenzzentrum für Obstbau-Bodensee (KOB) from 2016 to 2019.

\begin{tabular}{|c|c|c|c|c|c|c|c|}
\hline Year & Orchard Experiment & Levels & Repetitions & Crop load & $\begin{array}{l}\text { Mean fruit no. / } \\
\text { storage sample }\end{array}$ & Storage & Data \\
\hline \multirow{5}{*}{$2016 / 17$} & $\begin{array}{l}\text { Temp. cell division } \\
\text { post petalfall* }^{*}\end{array}$ & $\begin{array}{l}\text { cold }\left(-2{ }^{\circ} \mathrm{C}\right) \\
\text { ambient } \\
\text { warm }\left(+2{ }^{\circ} \mathrm{C}\right)\end{array}$ & $3 x$ & standard & 57 & \multirow{7}{*}{$\begin{array}{c}\text { Delayed- } \\
\text { CA } \\
\text { or } \\
\text { direct-CA } \\
\text { for } \\
5 \text { months }\end{array}$} & \multirow{4}{*}{$\begin{array}{l}\text { Pooled } \\
\text { per sector } \\
\text { per plot }\end{array}$} \\
\hline & Crop load & $\begin{array}{l}\text { light } \\
\text { standard } \\
\text { heavy }\end{array}$ & $3 x$ & $\begin{array}{l}\text { Light } \\
\text { standard } \\
\text { heavy }\end{array}$ & 56 & & \\
\hline & Calcium spraying & $\begin{array}{l}\text { With } \\
\text { without }\end{array}$ & $3 x$ & light & 58 & & \\
\hline & Harvest date & $\begin{array}{l}\text { standard } \\
\text { late }\end{array}$ & $3 x$ & standard & 59 & & \\
\hline & $\begin{array}{l}\text { Temp. preharvest }>10^{\circ} \mathrm{C} \\
\text { day and night }\end{array}$ & $\begin{array}{l}\text { ambient } \\
\text { warm }\end{array}$ & $1 \mathrm{x}$ & standard & 25 & & \multirow{8}{*}{$\begin{array}{l}\text { Pooled } \\
\text { per sector } \\
\text { per tree }\end{array}$} \\
\hline \multirow[t]{2}{*}{$2017 / 18$} & $\begin{array}{l}\text { Crop load nested within Temp. } \\
\text { cell division post petalfall }\end{array}$ & $\begin{array}{l}\text { cold }\left(-2^{\circ} \mathrm{C}\right) \\
\text { ambient } \\
\text { warm }\left(+2{ }^{\circ} \mathrm{C}\right)\end{array}$ & $3 x$ & $\begin{array}{l}\text { light } \\
\text { standard } \\
\text { heavy } \\
\end{array}$ & 19 & & \\
\hline & Calcium spraying & $\begin{array}{l}\text { with } \\
\text { without }\end{array}$ & $3 x$ & light & 30 & & \\
\hline \multirow{5}{*}{$2018 / 19$} & $\begin{array}{l}\text { Temp. cell division } \\
\text { post petalfall }\end{array}$ & $\begin{array}{l}\text { cold }\left(-2{ }^{\circ} \mathrm{C}\right) \\
\text { ambient } \\
\text { warm }\left(+2{ }^{\circ} \mathrm{C}\right)\end{array}$ & $3 x$ & standard & 20 & \multirow{5}{*}{$\begin{array}{c}\text { Delayed- } \\
\text { CA } \\
\text { for } \\
5 \text { and } \\
7 \text { months }\end{array}$} & \\
\hline & Crop load & $\begin{array}{l}\text { light } \\
\text { standard } \\
\text { heavy }\end{array}$ & $3 x$ & $\begin{array}{l}\text { light } \\
\text { standard } \\
\text { heavy }\end{array}$ & 25 & & \\
\hline & Calcium spraying & $\begin{array}{l}\text { with } \\
\text { without }\end{array}$ & $3 x$ & light & 19 & & \\
\hline & Harvest date & $\begin{array}{l}\text { early } \\
\text { standard } \\
\text { late } \\
\end{array}$ & $3 x$ & standard & 19 & & \\
\hline & $\begin{array}{l}\text { Temp. preharvest }>10^{\circ} \mathrm{C} \\
\text { night temperature }\end{array}$ & $\begin{array}{l}\text { ambient } \\
\text { warm }\end{array}$ & $4 x$ & $\begin{array}{l}\text { light } \\
\text { standard } \\
\text { heavy }\end{array}$ & 21 & & \\
\hline
\end{tabular}

\subsubsection{Cell division temperature treatments}

Air temperature treatments were conducted in spring in all three experimental years for three weeks post petalfall. There were three treatment levels (warm $+2{ }^{\circ} \mathrm{C}$ compared to ambient, ambient or cold $-2{ }^{\circ} \mathrm{C}$ compared to ambient). Treatments were replicated three times and conducted in plastic greenhouse tents built over the plots in the orchard using either small $2.4 \mathrm{~kW}$ domestic fan heaters placed on the ground or $3.0 \mathrm{~kW}$ cooling machines (Riedel, Kulmbach, Germany) mounted at the top of the tents covering the trees. The ambient control trees were covered in hail netting to adjust for the light reduction caused by the plastic sheeting and were not in a tent. Temperature difference controllers (HTronic TDR 2004, Hirschau, Germany) were used to control the heaters or cooling machines and 'ibutton' temperature dataloggers (Measurement Systems Ltd, Newbury, UK) placed at three heights within the tree canopies in each plot to record the temperature hourly. Cooling treatments were most effective during the night to maintain the intended $-2^{\circ} \mathrm{C}$ difference compared to ambient but were not effective when the sun shone brightly where the tents had to be opened and vented to maintain temperatures closer to ambient conditions. In 2017 , a damaging late spring frost $\left(-4.5^{\circ} \mathrm{C}\right)$ occurred during full flowering. The cell division temperature treatment trees at the KOB were able to be protected with plastic sheeting and heated.

Temperature data were used to calculate growing degree hours (GDH) by subtracting a base temperature of $10^{\circ} \mathrm{C}$ (as used by Lau, 1998; Volz et al., 2000) from the mean hourly air temperature and summing (e.g. $3^{\circ} \mathrm{C}$ above the base temperature for $1 \mathrm{~h}$ gives $3 \mathrm{GDHs}$ ). Hourly temperatures of $10^{\circ} \mathrm{C}$ or less were set to zero. 


\subsubsection{Preharvest temperature treatments}

Preharvest air temperature experiments during the final four weeks preharvest involved warm and ambient treatment levels only. In 2016, a small plastic greenhouse was built over one plot of seven trees and the air temperature maintained at $>10^{\circ} \mathrm{C}$ during the day and night up until harvest. In the frost year (2017/18) additional 'Braeburn' trees without frost damage were found on a commercial orchard at Kippenhausen some $25 \mathrm{~km}$ away from the KOB and eight experimental plots of four trees were established with five different timings of the warm periods, two levels of crop load (light or standard) and one replication (Table 2). Plastic greenhouse tents were built over the plots and heated $\left(>10^{\circ} \mathrm{C}\right)$ from the late afternoon until early morning.

In 2018/19, a replicated (4x) preharvest experiment was conducted at the KOB. Plots of seven trees were either heated in plastic greenhouse tents to maintain $>10^{\circ} \mathrm{C}$ at night or kept at ambient under one layer of hail net. In addition, three levels of crop load were nested within each temperature plot (crop load details follow below in section 2.1.3). Tents were opened in the morning and closed at night. Large roof windows were designed to maximise the amount of daylight reaching the trees and also to allow any daytime rainfall to wet the trees. Ambient plots were covered with hail netting to try and maintain similar lighting conditions over all plots.

In all study years, temperature dataloggers were placed at three heights with the tree canopies to record the temperature each hour and data used to calculate GDHs.

\subsubsection{Crop load treatments}

At the KOB in each experimental year, three levels of crop load were established as light, standard or heavy, corresponding to approximately $50 \%, 100 \%$ or $180 \%$ of a standard crop load, respectively (Table 1). Fruit numbers varied slightly each year due to differences in natural fruit-set, frost event and tree canopy growth. Hand thinning treatments were conducted during flowering and after June drop to establish the final crop load some 12 weeks preharvest. When bloom intensity was very heavy (2016/17), early flower cluster thinning was conducted to space clusters out at 10,20 or $30 \mathrm{~cm}$ with additional hand thinning of fruitlets conducted directly after June drop. In the frost year (2017/18) with limited tree availability, crop load treatments were nested within the cell division temperature plots. In this year little hand thinning was required as in each plot of seven trees there were either two or three trees with a light, standard or heavy crop load. However due to the frost the fruit distribution over the tree was uneven with more fruit at the top and less at the bottom.

In the Kippenhausen orchard preharvest experiment, mature `Braeburn' trees (3.1 by 0.9 $\mathrm{m}$ spacing, $3.5 \mathrm{~m}$ in height) were hand thinned some 5 weeks prior to harvest to two levels of crop load as light (50\%) or standard (100\%).

In 2018/19 sufficient trees were available for all experiments so in addition to a crop load experiment, three levels of crop load were nested within the preharvest temperature experiment plots.

\subsubsection{Calcium treatments}

At the KOB in each experimental year, calcium spray treatments were conducted (Table 1). Calcium chloride at a dose rate of 7 to $10 \mathrm{~kg} / \mathrm{ha}$ was sprayed weekly or not from July until harvest. Two adjacent rows were either sprayed or not with three plots for assessment replicated down each row. Treatments were sprayed using an orchard sprayer.

\subsubsection{Harvest date treatments}

Harvest date experiments were conducted in 2016/17 and 2018/19 for two or three levels (standard or late) or three levels (early, standard or late) where early was $7 \mathrm{~d}$ before standard and late some 10-14 d later. Harvest decisions followed commercial practice as explained in section 2.2. 
Table 2. Preharvest air temperature treatments conduced at Kippenhausen in 2017/18. Harvest date 18 October, $N=$ approximately 200 fruit assessed per plot (4 trees).

\begin{tabular}{|c|c|c|c|c|}
\hline \multirow{2}{*}{$\begin{array}{l}\text { Temp. treatment, } \\
\text { Crop load level }\end{array}$} & \multicolumn{3}{|c|}{$\begin{array}{l}\text { Warm phase preharvest temp. } \\
\text { treatments } \sim>10^{\circ} \mathrm{C} \text { for } 10 \text { nights }\end{array}$} & \multirow{2}{*}{$\begin{array}{c}\text { Mean core-browning } \\
\% \text { incidence (severity index) }\end{array}$} \\
\hline & 16-26 Sep. & 26 Sep. -06 Oct. & 06-17 Oct. & \\
\hline ambient, light & - & - & - & $63 \%(18)$ \\
\hline ambient, standard & - & - & - & $55 \%(12)$ \\
\hline warm phase 1 , standard & $\mathrm{x}$ & - & - & $41 \%(9)$ \\
\hline warm phase 2 , standard & $\mathrm{x}$ & $\mathrm{x}$ & & $38 \%(8)$ \\
\hline warm phase3, light & $\mathrm{x}$ & $\mathrm{x}$ & $\mathrm{x}$ & $27 \%(7)$ \\
\hline warm phase 3 , standard & $\mathrm{x}$ & $\mathrm{x}$ & $\mathrm{x}$ & $13 \%(3)$ \\
\hline warm phase 4 , standard & - & $\mathrm{x}$ & $\mathrm{x}$ & $12 \%(3)$ \\
\hline warm phase 5 , standard & - & - & $\mathrm{x}$ & $17 \%(4)$ \\
\hline
\end{tabular}

\subsection{Harvesting and postharvest $\mathrm{CA}$ storage conditions}

Standard apple maturity tests for fruit firmness (FF N), starch staining pattern index (scale 1-10) and soluble solids content (SSC \%) were used to calculate a harvest index [FF/(SSC $x$ starch)] and set a harvest window following the usual commercial practice in Southwest Germany (Streif and Kittemann, 2018). At-harvest maturity data (three repetitions of eight fruit) from 2016 to 2018 are shown in Table 3. At-harvest, all fruit from trees were picked separately by sector. Immediately after harvest, the 'Braeburn' fruit were sorted (very small fruit $<60 \mathrm{~mm}$ removed) and randomly allocated into storage treatments. In 2016 and 2017 fruit were placed in CA for five months in either a storage condition intended to reduce 'Braeburn' browning disorder (BBD) by low $\mathrm{CO}_{2}$ concentrations $\left(1^{\circ} \mathrm{C}, 21 \mathrm{~d}\right.$ delayed-CA establishment, $1 \mathrm{kPa} \mathrm{O},<0.7 \mathrm{kPa} \mathrm{CO}$ ) or a storage condition intended to induce $\mathrm{BBD}$ symptoms $\left(1{ }^{\circ} \mathrm{C}\right.$, direct-CA, $2.0 \mathrm{kPa} \mathrm{O}_{2}$ and $2.3 \mathrm{kPa} \mathrm{CO}$ ). In 2018 , all fruit were stored in delayed-CA as given above and removed from storage after five and seven months.

Table 3. Full bloom and harvest dates and at-harvest maturity parameters of fruit firmness (FF), soluble solids content (SCC), starch pattern index and harvest index [FF/(SSC x starch)] for experiments on 'Braeburn' apples in 2016 to 2018.

\begin{tabular}{|c|c|c|c|c|c|c|c|c|}
\hline Year & $\begin{array}{c}\text { Full } \\
\text { Bloom }\end{array}$ & Location & Experiment & $\begin{array}{c}\text { Harvest } \\
\text { date }\end{array}$ & $\begin{array}{l}\mathrm{FF} \\
(\mathrm{N})\end{array}$ & $\begin{array}{l}\text { SSC } \\
(\%)\end{array}$ & $\begin{array}{l}\text { Starch } \\
(1-10)\end{array}$ & $\begin{array}{l}\text { Harvest } \\
\text { Index** }\end{array}$ \\
\hline $\begin{array}{l}2016 \\
/ 17\end{array}$ & 30. Apr & \multirow{3}{*}{$\mathrm{KOB}$} & $\begin{array}{c}\text { Crop load* } \\
\text { Harvest-late }\end{array}$ & $\begin{array}{l}\text { 16/17. Oct } \\
\text { 02. Nov }\end{array}$ & $\begin{array}{l}108 \\
105\end{array}$ & $\begin{array}{l}11.3 \\
12.0\end{array}$ & $\begin{array}{l}3.3 \\
4.8\end{array}$ & $\begin{array}{l}0.29 \\
0.19\end{array}$ \\
\hline $\begin{array}{c}2017 \\
/ 18\end{array}$ & 18. Apr & & Crop load* & 17. Oct & 96 & 11.2 & 5.6 & 0.16 \\
\hline $\begin{array}{c}2018 \\
/ 19\end{array}$ & 23. Apr & & $\begin{array}{c}\text { Crop load* }^{*} \\
\text { Harvest late } \\
\text { Harvest very late }\end{array}$ & $\begin{array}{l}\text { 03. Oct } \\
\text { 10. Oct } \\
\text { 17. Oct }\end{array}$ & $\begin{array}{l}97 \\
94 \\
93 \\
\end{array}$ & $\begin{array}{l}12.1 \\
11.8 \\
12.5 \\
\end{array}$ & $\begin{array}{l}3.3 \\
3.3 \\
4.1 \\
\end{array}$ & $\begin{array}{l}0.25 \\
0.25 \\
0.18 \\
\end{array}$ \\
\hline $\begin{array}{c}2017 \\
/ 18\end{array}$ & 21. Apr & $\begin{array}{l}\text { Kippen- } \\
\text { hausen }\end{array}$ & Temp. preharvest & 18. Oct & 89 & 11.2 & 5.6 & 0.14 \\
\hline
\end{tabular}

* Values for the middle sector of standard crop load trees. Other maturity tests taken on same day showed similar values regardless of crop load / tree sector / temperature cell division treatment. ${ }^{* *}$ Harvest index FF units as kg/ $\mathrm{cm}^{2}$.

\subsection{Assessments at storage removal}

At storage out-turn, fruit samples (Table 1) were kept at room temperature for $7 \mathrm{~d}$ and then all fruit $(>10,000$ in each study year) were individually assessed by trained staff for external disorders (bitter pit, $\mathrm{CO}_{2}$ damage, superficial scald) and by cutting for internal disorders (core browning, flesh browning, cavities, bitter pit). For assessments in 2016, fruit samples were pooled together from each treatment repetition per sector. In 2017 and 2018 fruit were assessed separately for each tree and sector. All disorders were scored on the same 0 to 3 scale (in 0.5 steps), where $0=$ no symptoms and $3=$ most severe symptoms. Apples with only slight symptoms (i.e. scores of 1 and below) would most likely be acceptable for consumers. Incidence was calculated as the total number of fruit with a score $\geq 0.5$ divided by the total fruit number expressed as a percentage. 
A disorder severity index (0-100) was calculated where $\mathrm{i}=$ disorder score as either 0 , $0.5,1,1.5,2,2.5,3, n_{i}=$ number of fruit with score $\mathrm{i}$ and $\mathrm{N}=$ total number of fruit assessed.

$$
\text { Severity Index }=\frac{\sum_{i=0}^{i=3}\left(n_{i} \times i\right) \times 100}{N * 3}
$$

\subsection{Statistics and data analysis}

The disorder score data obtained after storage and shelf-life are shown as the mean percentage incidence and mean severity index (0-100) with the standard deviation (sd).

The core browning data from the 2016/17 and 2017/18 crop load and temperature experiments (cell division and preharvest) were analysed further using boxplots and receiver operating characteristic (ROC) curves calculated with the software package ' $p R O C$ ' available for R (Robin et al., 2011). ROC curve analyses are used in many medical fields to assess the performance of biomarkers as binary classifiers to predict disease risk. In postharvest biology, ROC curves have found application in fruit sorting when VIS/NIR non-destructive equipped graders are used to assess internal fruit quality (Walsh et al., 2020). And recently, Leisso et al. (2019) used ROC curves to assess the influence of preharvest factors like GDD, chilling hours and other fruit quality parameters as binary classifiers to predict the risk of disorders developing in 'Honeycrisp' apples. Here we have followed a similar approach.

As a non-parametric assessment of binary classifier performance ROC curves are much less demanding for the assumptions of data normality, equal variance and balanced datasets as required for statistical methods based on probability distributions with deviations from a mean or variance value. ROC curves are commonly based on the frequencies with which a classifier produces true positives (TP $=$ fruit with disorder), true negatives (TN $=$ sound fruit), false positives (FP = sound fruit classed as disordered) and false negatives ( $F N=$ disordered fruit classed as sound) as shown as an example in Fig. 1.

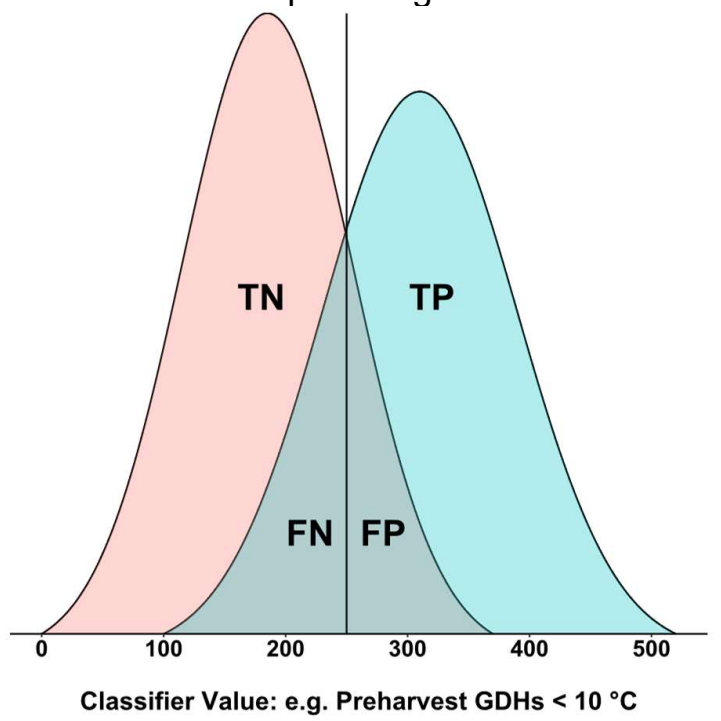

Fig. 1. Theoretical distributions for sound fruit ( $T N=$ true negative) and disordered fruit (TP = true positive) separated by a binary classifier (vertical line) at a cut-off value of $\sim 250$ growing degree hours $<10^{\circ} \mathrm{C}$ in the preharvest period. TN values on the right of the cut-off become false positives (FP) and TP values on the left become false negatives (FN).

In all the ROC curves given below, the $y$-axis shows the true positive percentage (also known as sensitivity $)=T P /(T P+F N)$ with the false positive percentage (1-specificity) $=1-(T N /$ $(\mathrm{TN}+\mathrm{FP})$ ) on the $\mathrm{x}$-axis. The area under the curve (AUC) is shown in plots, as it is an important measure of classifier performance. When the AUC is close to $50 \%$, the classifier has no power to discriminate between sound and disordered fruit, while AUC values of $\sim 75 \%$ and above 
show good utility, with a perfect classifier having an AUC value of $100 \%$. The 'pROC' software package allowed $95 \%$ confidence intervals (Cls) for the AUC to be calculated using 2000 stratified bootstrapping resamplings, these Cls are displayed in the plots as a shaded area. The Cls show the range of values the AUC would take if the experiment was repeated many times under identical conditions, but note also these Cls are not appropriate when the same classifier is applied in other situations. In addition, the 'pROC' software can calculate an optimal balance of true positive and false positive percentages and give the corresponding threshold value of the classifier. However, this threshold value may not always be appropriate in a practical sense i.e. when the negative cost of FNs is high and results in product rejection by a customer / end consumer.

ROC curve analyses were conducted for three different classifiers of core browning incidence and severity: 1) $\mathrm{GDH}>10^{\circ} \mathrm{C}$ for the cell division treatments; 2) $\mathrm{GDH}<10{ }^{\circ} \mathrm{C}$ for the preharvest treatments and; 3 ) crop load, as the percentage of a standard full crop load per tree sector $(100 \%)$. The mean core browning data from each sample were subjectively allocated into two binary categories as either high or no / low incidence and severity. To achieve binary categories for the ROC curve analysis, where each category contained a reasonable number of values, a subjective cut-off value of 30 was used for the severity index to separate the samples when incidence was high in 2016/17 and when severity was much lower in 2017/18, a $30 \%$ incidence threshold was used. The boxplots summarise the binary distributions but do not show $p$ values as most of these data were skewed i.e. non-normal.

\section{RESULTS AND DISCUSSION}

\subsection{Occurrence of browning disorders during the three experimental years}

The incidence of internal browning disorders varied greatly over the three study years (Table 4). The 2016/17 season was a severe internal browning year for 'Braeburn' with a mean core browning incidence (severity) of $58 \%(16)$ and $82 \%$ (31) over all field treatments in delayed-CA and direct-CA, respectively. The mean incidence (severity) of cavities was $9 \%$ (2) and $33 \%$ (9) over all field treatments in delayed-CA and direct-CA, respectively. The incidence of flesh browning was close to zero.

Table 4. Mean incidence and severity (over all field treatments) of storage disorders in 'Braeburn' apples after seven day shelf-life following direct-CA or delayed-CA from the Kompetenzzentrum Obstbau-Bodensee (KOB) and Kippenhausen orchards over three different years.

\begin{tabular}{|c|c|c|c|c|c|c|c|}
\hline \multirow[b]{2}{*}{ Year } & \multirow[b]{2}{*}{$\begin{array}{l}\text { Storage } \\
\text { duration }\end{array}$} & \multirow[b]{2}{*}{ Orchard } & \multirow[b]{2}{*}{ Symptom } & \multicolumn{2}{|c|}{ Delayed-CA } & \multicolumn{2}{|c|}{ Direct-CA } \\
\hline & & & & $\begin{array}{c}\text { Incidence } \\
(\%)\end{array}$ & $\begin{array}{l}\text { Severity } \\
(1-100)\end{array}$ & $\begin{array}{c}\text { Incidence } \\
(\%)\end{array}$ & $\begin{array}{l}\text { Severity } \\
(1-100)\end{array}$ \\
\hline \multirow{3}{*}{$2016 / 17$} & \multirow{15}{*}{$\begin{array}{c}5 \\
\text { months }\end{array}$} & \multirow{3}{*}{ KOB } & Core browning & 58 & 16 & 82 & 31 \\
\hline & & & Flesh browning & 0 & 0 & 0 & 0 \\
\hline & & & Cavities & 9 & 2 & 33 & 9 \\
\hline \multirow{7}{*}{$2017 / 18$} & & Both orchards & External $\mathrm{CO}_{2}$ & 0 & 0 & 31 & 17 \\
\hline & & \multirow{6}{*}{ Kippenhausen } & Core browning & 37 & 12 & \multirow{6}{*}{\multicolumn{2}{|c|}{ n.a. }} \\
\hline & & & Flesh browning & 4 & 2 & & \\
\hline & & & Cavities & 3 & 1 & & \\
\hline & & & Core browning & 33 & 8 & & \\
\hline & & & Flesh browning & 7 & 2 & & \\
\hline & & & Cavities & 0 & 0 & & \\
\hline \multirow{10}{*}{$2018 / 19$} & & \multirow{10}{*}{ KOB } & Core browning & 5 & 1 & \multirow{10}{*}{\multicolumn{2}{|c|}{$\begin{array}{c}\text { No } \\
\text { Direct } \\
\text { CA storage }\end{array}$}} \\
\hline & & & Flesh browning & 0 & 0 & & \\
\hline & & & Cavities & 0 & 0 & & \\
\hline & & & Bitter pit & 22 & 9 & & \\
\hline & & & Superficial scald & 8 & 2 & & \\
\hline & \multirow{5}{*}{$\begin{array}{c}7 \\
\text { months }\end{array}$} & & Core browning & 24 & 6 & & \\
\hline & & & Flesh browning & 0 & 0 & & \\
\hline & & & Cavities & 0 & 0 & & \\
\hline & & & Bitter pit & 16 & 6 & & \\
\hline & & & Superficial scald & 28 & 8 & & \\
\hline
\end{tabular}


In 2017/18, the severe frost event at the KOB during flowering strongly affected the incidence of storage disorders. Apples in direct-CA were extremely susceptible to external $\mathrm{CO}_{2}$ damage (bronzed areas on the fruit skin, mostly sunken with irregular shaped edges) with a high incidence (31\%) over all treatments, while fruit in delayed-CA showed no incidence (Table 4). Frosts during bloom can lower the apples' tolerance for stress factors like high $\mathrm{CO}_{2}$, low $\mathrm{O}_{2}$ or low temperatures (Little and Holmes, 2000). Furthermore, an assessment of internal browning symptoms for the direct-CA storage samples was not possible. Core and flesh browning symptoms could not be clearly separated as internal $\mathrm{CO}_{2}$ damage (browning with numerous large cavities) was also present in the majority of samples. Thus, only data for the delayed-CA storage samples from 2017/18 are presented. At the KOB, the incidence (severity) of core browning, flesh browning and cavities over all field treatments was $37 \%$ (12), $4 \%$ (2) and $3 \%(1)$, respectively and for the Kippenhausen orchard, symptoms were broadly similar to the KOB with $33 \%(8), 7 \%(2)$ and $0 \%(0)$, respectively (Table 4).

In 2018/19 all fruit were stored in delayed-CA storage and removed at five and seven months. The incidence (severity) of core browning over all treatments was $5 \%$ (1) and $24 \%$ (6) at the first and second storage removals, respectively. There was no incidence of flesh browning or cavities. 2018/19 was a bitter pit and superficial scald year (Table 4). Our observations of fruit industry pack-outs for 'Braeburn' over numerous years together with our storage results in this three year study suggest seasons with a high incidence of bitter pit are in general not severe internal browning years and vice versa.

Over the three seasons, neither the calcium spray treatments nor the different harvest timing showed clear effects on the postharvest browning disorders and these data are not discussed further.

\subsection{Cell division temperature experiments}

The spring temperature field treatments aimed to influence growth processes occurring during cell division and it was difficult to maintain the intended temperatures. During the warmest parts of the day there were clear temperature gradients between the top and bottom of the trees within both the warm and cold treatments. During the day, the desired temperature differences $\left(\triangle+/-2^{\circ} \mathrm{C}\right)$ to the ambient air temperatures were mostly not achieved and conditions in the plastic tents were too warm when the sun shone strongly around the middle of the day. However, at night there were minimal temperature gradients and the desired temperature differentials were generally well maintained. In each of the three study years, when the tents were removed after the three week post petal fall treatment period, there was a mean fruit diameter of $20 \mathrm{~mm}$ in the ambient treatment and mean diameters of $+/-2 \mathrm{~mm}$ for the warm and cold treatments, respectively. Apple fruit are known to grow (expand) mostly at night (Lang, 1990) when leaf transpiration is at a minimum, so we assume that the night temperatures were mainly responsible for these initial differences in fruit diameter. After the treatments were removed and all plots experienced ambient conditions until harvest, the cold treated fruit showed a higher relative growth rate for around five weeks and reached a similar mean fruit size as the ambient treated fruit but never exceeded it. The warm treated fruit maintained the initial difference of approximately $10 \%$ larger fruit size over the ambient fruit until harvest. Our growth rate data are exactly in line with those described by Warrington et al. (1999) working with temperature treatments applied during cell division to potted apple trees in growth chambers and then moved outside to ambient conditions. However, unlike Warrington et al. (1999) we found no differences between treatments for fruit maturity at harvest (harvest index).

In 2016/17 and 2018/19 all trees in the cell division temperature plots were hand-thinned to a standard crop load. In 2017/18, three levels of crop load were nested within each temperature treatment plot. These crop load differences were established early during bloom and adjusted slightly by hand thinning when the plastic tents were removed. We did not determine the internal cell structure at-harvest for possible differences in cell size, cell number or intercellular space (porosity). How apple fruit growth is influenced by the interaction of orchard air temperatures and differences in crop load is by no means clear and it is an ongoing research question (Malladi, 2020). Unpublished work suggests higher temperatures during cell division result in the fruit completing a set number of cell division cycles in a shorter time, thus 
allowing the fruit more time on the tree until harvest to grow larger, compared to fruit growing under cooler temperatures which take longer to complete the same number of cell divisions and are smaller at-harvest (Hirst, 2016). While differences in crop load and timing of when the final crop load is established on the tree will result in fruit having differences in carbohydrate supply, with the final fruit size due largely to differences in cell numbers (Hirst, 2016).

We can find no literature on how spring air temperatures or changes in crop load during fruit development can influence the intercellular space of apples at-harvest and subsequently how the intercellular space may change during postharvest handling and CA storage. However, work by Ruess and Stösser (1993) determined changes in the intercellular volume for five apple cultivars (not including 'Braeburn') from two weeks after full bloom until harvest and during 20 weeks cool storage in air. All fruit were sourced from the same orchard site and trees were controlled for a similar crop load (standard for each cultivar). Results (common for all tested cultivars) showed that the intercellular space did not develop to any large extent until after cell division was completed some four to six weeks after full bloom. For a specific cultivar larger fruit (with a lower specific gravity) showed a higher intercellular volume. Thus, we have reasonable grounds to conclude our experimental cell division temperature treatments produced three distinct groups of fruit (each with very different growth rates and final mean fruit size) that would all have important differences in cellular structure at-harvest and different gas exchange characteristics during postharvest storage. In particular, for the 2017/18 season when fruit development in the orchard was influenced by both temperature treatments and differences in crop loads that were established very early during bloom.

However, when all available data from 2016/17 are placed into binary classes for GDH $>10{ }^{\circ} \mathrm{C}$ and analysed as a ROC curve there is no utility for GDHs during this spring postbloom period to predict core browning (Fig. 2A, B). While the box plot shows a slightly higher median value for high severity, the ROC curve analysis for $\mathrm{GDHs}>10^{\circ} \mathrm{C}$ show an AUC value of $54 \%$ (Fig. 2A, B). Identical AUC values are obtained for $\mathrm{GDHs}<10^{\circ} \mathrm{C}$ and the data from $2017 / 18$ also shows no utility (not presented). Results could not be confirmed in 2018/19 because of a very low core browning incidence. Overall study years we have no evidence that spring temperatures can influence browning disorders during storage and our initial hypothesis that warm temperatures (within the range of $\triangle+/-2{ }^{\circ} \mathrm{C}$ ) after bloom during cell division result in browning disorders should be rejected. 

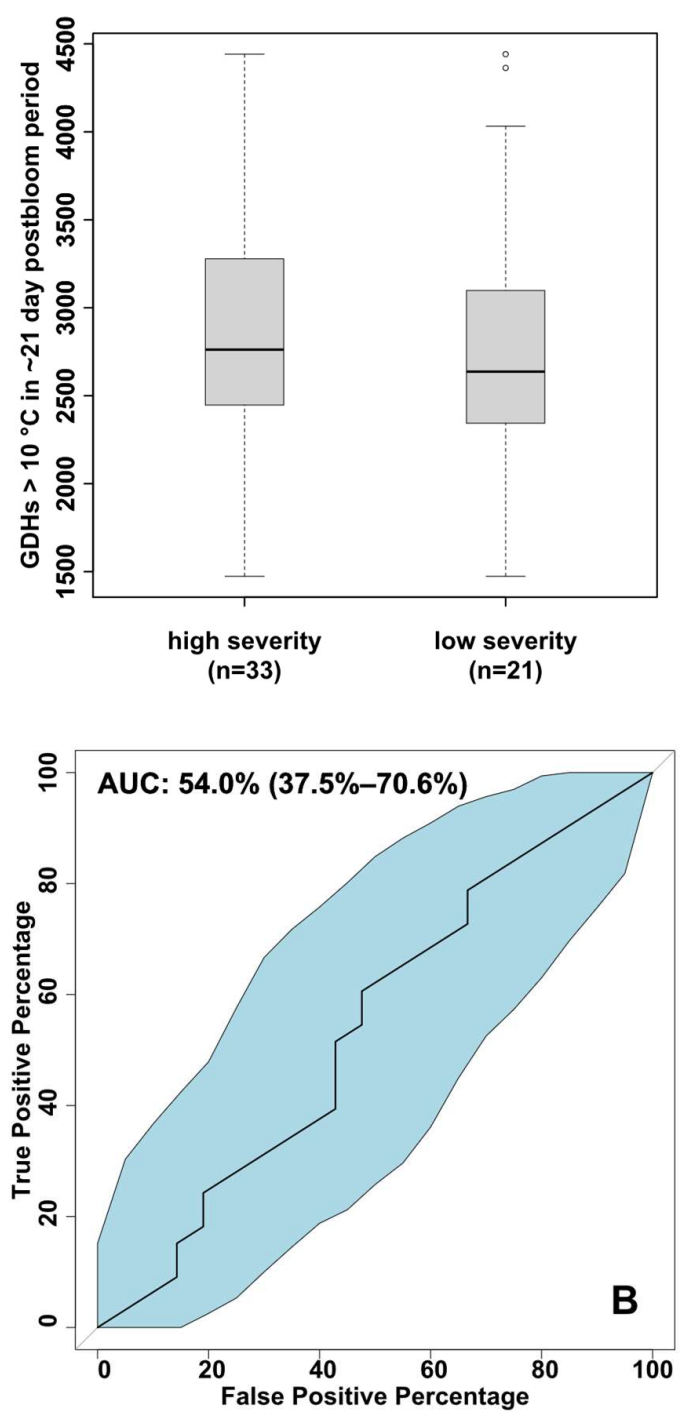

Fig. 2. A) Boxplot of core browning severity in 'Braeburn' apples in $2016 / 17$ at the KOB after five months CA storage versus growing degree hours $(\mathrm{GDH})>10^{\circ} \mathrm{C}$ in the three week postbloom period. B) Receiver operating characteristic (ROC) curve for $\mathrm{GDHs}>10^{\circ} \mathrm{C}$ in the three week postbloom period to predict core browning severity. Shaded area is the $95 \% \mathrm{Cl}$ for the ROC curve. Number of samples $=54$.

\subsection{Temperature pre-harvest experiments}

The preharvest temperature experiment in 2016/17 had a very pronounced effect on core browning. Trees maintained at $>10^{\circ} \mathrm{C}$ in the four week preharvest period show very low core browning with a mean incidence (severity) of $6 \%(2)$ from both storage conditions compared to fruit from trees at ambient conditions with $56 \%$ (18). The binary classifier results are shown in Fig. 3A, B with a very large AUC value of $91.1 \%$. The ROC curve suggests a threshold value of $484 \mathrm{GDHs}<10^{\circ} \mathrm{C}$ during the 4 week preharvest period shown as the dotted horizontal line in Fig. 3A, from the $x, y$ coordinates of $11 \%$ false positive percentage and $95 \%$ true positive percentage in Fig. 3B. 

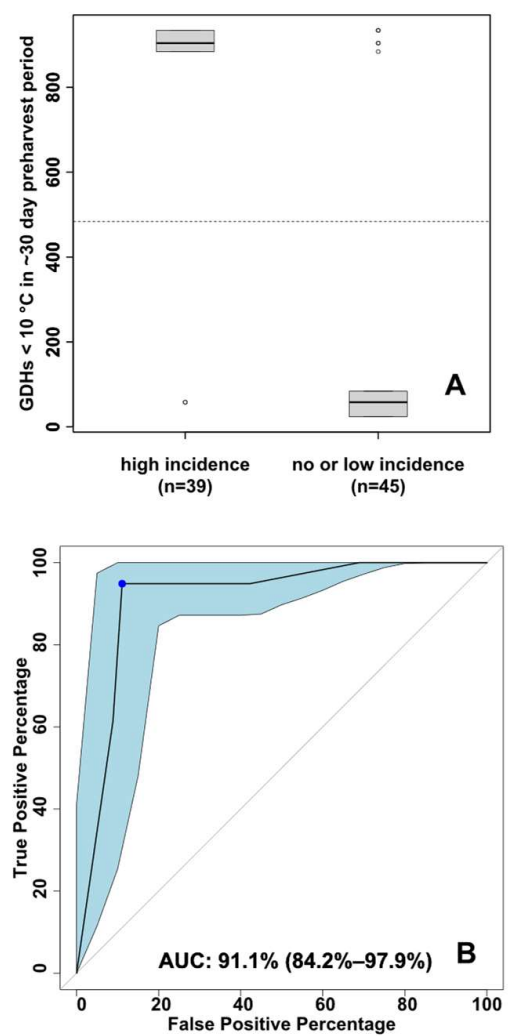

Fig. 3. A) Boxplot of core browning incidence in 'Braeburn' apples in 2016/17 at the KOB after five months CA storage versus growing degree hours $(\mathrm{GDH})<10^{\circ} \mathrm{C}$ in the 4 week preharvest period. Optimal threshold from the Receiver operating characteristic (ROC) curve of $484 \mathrm{GHDs}$ $<10{ }^{\circ} \mathrm{C}$ shown as the dotted horizontal line. B) ROC curve for GDHs $<10{ }^{\circ} \mathrm{C}$ in the four week preharvest period to predict core browning severity. Shaded area is the $95 \% \mathrm{Cl}$ for the ROC curve. Number of samples $=84$.

In the Kippenhausen orchard preharvest temperature experiment, eight experimental treatments were established on 'Braeburn' trees (Table 2). The trends in mean core browning incidence (severity) for each treatment are given in Table 2. Warm treatments closer to harvest appear more effective at reducing core browning. The boxplot (Fig. 4) and ROC curve analyses (Fig. 5) also show the same trend with the best AUC value of $88.6 \%$ given by the ROC curve based on predictors for the accumulated GDHs $<10{ }^{\circ} \mathrm{C}$ over the last $11 \mathrm{~d}$ preharvest compared to either the 21 or $30 \mathrm{~d} \mathrm{GDH}<10^{\circ} \mathrm{C}$. However, the differences between the three ROC curves are not significant. The optimal GDH $<10^{\circ} \mathrm{C}$ threshold values calculated from the ROC curves (shown as dotted lines in the boxplots (Fig. 4) are 337, 322 and 12 for the 30, 21 and $11 \mathrm{~d}$ preharvest periods, respectively.

$2018 / 19$ was not a severe browning year (Table 4). However, the 2018/19 results are in line with the other two seasons. The first storage removal shows core browning incidence (severity) for all the warm treatments of $1 \%(0)$ regardless of crop load (Table 5). At the second storage removal warm treatments show approximately half the incidence (severity) compared to the fruit from ambient conditions. Over the three study years, warm preharvest conditions are protective for core browning in 'Braeburn' and confirm our initial hypothesis.

We know of no other literature where preharvest temperature treatments have been conducted on 'Braeburn' in regard to postharvest disorders. However, our results are in agreement with the GDD observations from a range of workers (Lau, 1998; Volz et al., 2000) that link 'Braeburn' browning incidence to cool preharvest conditions, in particular during the last 30 d preharvest as recorded by Volz et al. (2000). 
We also note that for the apple cultivar 'Fuji', cooler growing conditions during fruit maturation are associated with a higher incidence of watercore, commonly understood as a disturbance in carbohydrate uploading into the fruit (Ferguson et al., 1999).

Our results from three consecutive seasons show strong evidence that temperature conditions very close to harvest can influence browning susceptibility, but without further experimental data we cannot explain a possible mechanism, however, we can share some ideas.

Apples in the warm preharvest treatment in 2016 show a trend for higher starch degradation at-harvest with a starch pattern index of 4.1, a FF of $99 \mathrm{~N}$ and a SSC of $10.5 \%$ compared to $3.5,103 \mathrm{~N}$ and $10.6 \%$, in ambient conditions, respectively. In 2018, warm preharvest treatments also show a similar trend for higher starch degradation (Table 5), with a mean starch pattern index of 3.6, a FF of $92 \mathrm{~N}$ and a SSC of $11.5 \%$ compared to $2.9,93 \mathrm{~N}$ and $11.3 \%$, in ambient conditions, respectively. No maturity data for the different treatment levels are available from the Kippenhausen study in 2017. In summary, warm preharvest treated fruit compared to ambient fruit appear slightly more mature with an altered carbohydrate status i.e. more starch conversion but similar or slightly raised SSC. But these trends do not fit well with the literature and our experience where starch clearing and maturation is higher under cooler conditions (Smith, 1979; Sperling et al., 2017). The apparent higher starch conversion in the warm treated plots may be due to a smaller day night temperature difference and lower starch accumulation in the fruit (Toivonen, 2019). These aspects of carbohydrate metabolism require closer study during fruit maturation, in particular given that autumn temperatures are now in general warmer and diurnal temperature differences often less marked than were usual in the past. Fruit continue to upload carbohydrates while on the tree. Carbohydrate uploading via the apoplast is the most important pathway for sugars during the final stages of apple maturation and is an energy intensive process (Zhang, 2004). Fruit growth (expansion) is largely driven by osmotic pressure created by sugar accumulation in the vacuoles (Malladi, 2020) and largely occurs at night (Lang, 1990). After the first experimental year, the preharvest warming treatments were applied at night only to coincide with when cell expansion was mostly taking place. Thus, fruit from the preharvest warming treatments may have also had an altered energy / carbohydrate status at-harvest due to differences in uploading processes and these effects could be protective against browning occurring during postharvest handling and storage. However, fruit growth also involves dynamic ongoing changes in particular with the intercellular volume both on and off the tree (Ruess and Stösser, 1993). Such internal structural changes within the fruit will affect gas exchange, these changes could be protective or not in regard to browning disorders. Fruit diameter growth was measured in this study but did not show any differences between preharvest temperature treatments. Measuring fruit diameter only will underestimate fruit growth during final maturation (Malladi, 2020), thus we cannot exclude that there may have been treatment differences in fruit length or growth expansion in and around the fruit shoulders of the calyx or stem ends.

Some other environmental factors that could have influenced the fruits' susceptibility to browning during final maturation were not controlled for in our experimental setup. Rainfall occurring in the days immediately preharvest is a factor now known to affect internal browning incidence in some of the more recent apple cultivars with a very firm fruit flesh texture (Johnston, 2018). The experimental tents used in the study were fitted with large roof windows to be open during the day to maximise photosynthesis and carbohydrate supply from the leaves and also to allow any daytime rainfall to wet the trees and fruit. But even so the tent treatments very likely reduced the amount of free moisture on the fruit skin from dew or fog (common in autumn in this growing region) with the warm treated fruit being somewhat drier overnight compared to ambient conditions, although we did not specifically determine this. It is possible for apple fruit to uptake water osmotically through the skin (Lang, 1990) and as the skin of 'Braeburn' apples is the major barrier to gas exchange, any change in skin permeance could also have affected browning susceptibility. 
Experiments were intended to test our hypothesis that warm preharvest conditions will reduce postharvest browning and also provide some data as to when warming (time before harvest) was most effective. The results show that preharvest conditions can markedly change browning disorder incidence with evidence that conditions directly before harvest (within the last 11 days) can be effective.

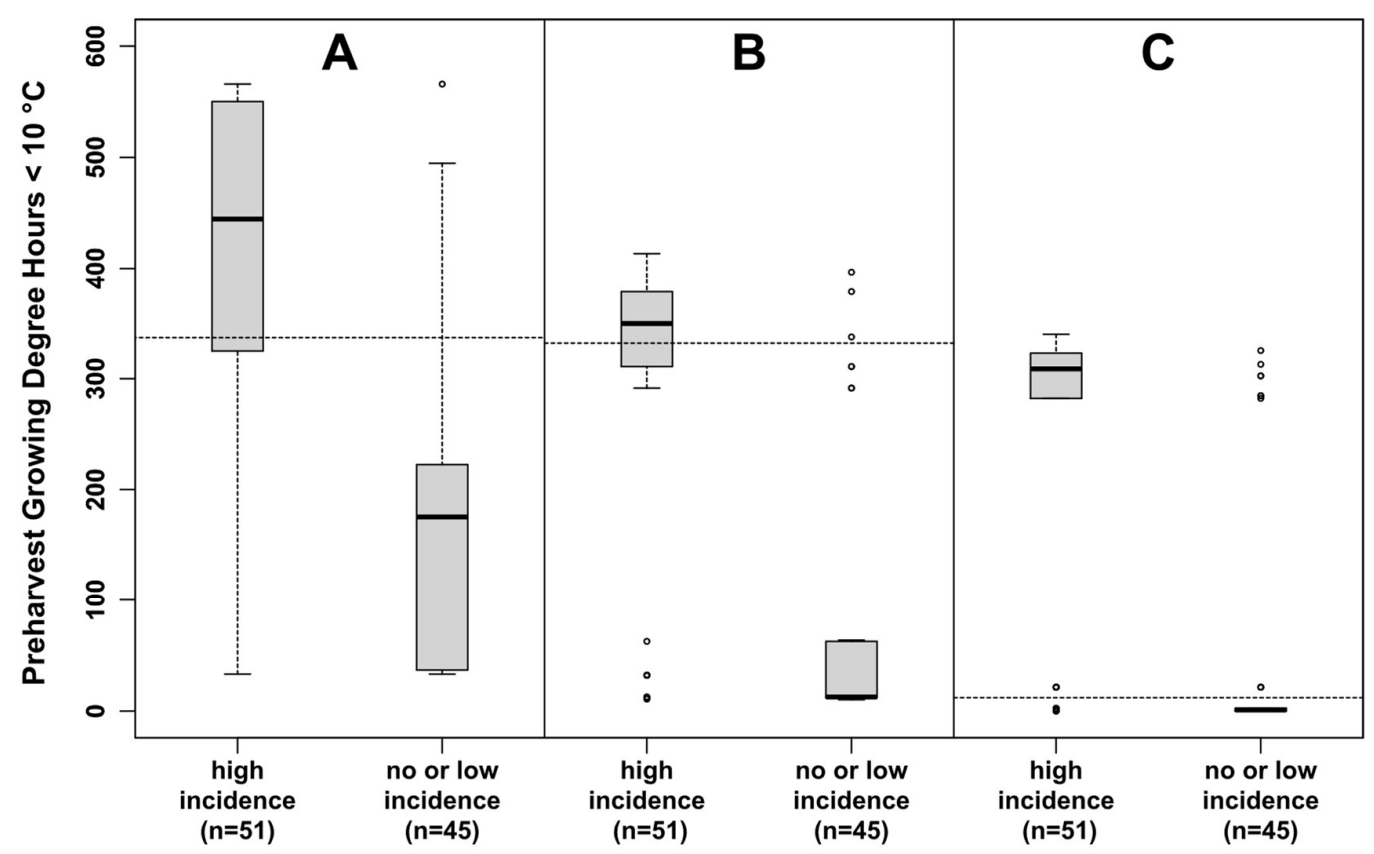

Fig. 4. Boxplots of core browning incidence in 'Braeburn' apples in 2017/18 at the Kippenhausen orchard after five months delayed-CA storage versus growing degree hours $(\mathrm{GDH})<10{ }^{\circ} \mathrm{C}$ in the preharvest period. A) From 30 days preharvest. B) From 21 days preharvest. C) From 11 days preharvest. Dotted horizontal lines show the GHD $<10{ }^{\circ} \mathrm{C}$ threshold values calculated from the receiver operating characteristic curves to separate high or no/low incidence. Number of samples $=96$. 


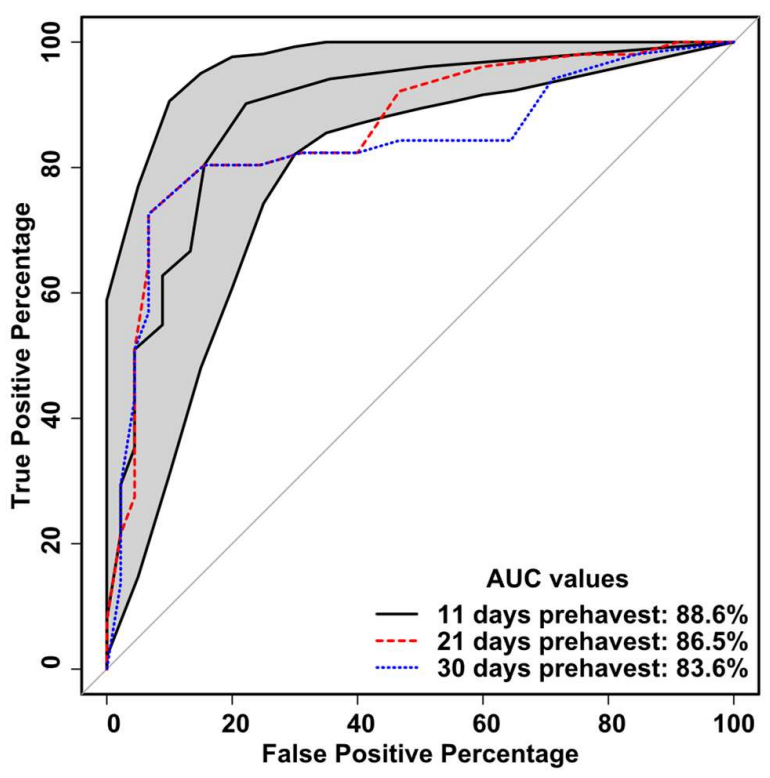

Fig. 5. Three receiver operating characteristic (ROC) curves for core browning incidence in 'Braeburn' apples in 2017/18 from the Kippenhausen orchard after delayed-CA storage for the predictor growing degree hours $(\mathrm{GDH})<10{ }^{\circ} \mathrm{C}$ in the preharvest period. Black, red and blue lines show the ROC curves for the 11,21 or 30 day preharvest warming treatments, respectively. Shaded area shows the $95 \%$ Cls for the ROC curves for the 11 day preharvest period (solid black line). Differences between all curves are not significant. Number of samples $=96$.

Table 5. Incidence and severity of core browning and the starch pattern index at-harvest after five and seven months delayed-CA storage for the temperature preharvest experiment in 2018/19 at the Kompetenzzentrum Obstbau-Bodensee (KOB).

\begin{tabular}{|c|c|c|c|c|c|c|c|c|}
\hline \multirow{3}{*}{ Storage } & \multirow{2}{*}{\multicolumn{2}{|c|}{ Treatment }} & \multicolumn{4}{|c|}{ Core browning } & \multirow{2}{*}{\multicolumn{2}{|c|}{ Starch pattern index * }} \\
\hline & & & \multicolumn{2}{|c|}{ incidence } & \multicolumn{2}{|c|}{ severity } & & \\
\hline & Temp. & Crop load & $\%$ & (sd) & $0-100$ & (sd) & $1-10$ & (sd) \\
\hline \multirow{6}{*}{ months } & ambient & heavy & 0 & $(0.0)$ & 0 & $(0.0)$ & 2.5 & $(0.3)$ \\
\hline & ambient & standard & 3 & (6.3) & 1 & $(1.1)$ & 3.2 & $(0.3)$ \\
\hline & ambient & light & 13 & $(5.4)$ & 2 & (1.1) & 3.1 & $(0.2)$ \\
\hline & warm & heavy & 0 & $(0.5)$ & 0 & $(0.1)$ & 2.9 & $(0.6)$ \\
\hline & warm & standard & 1 & $(1.4)$ & 0 & $(0.3)$ & 4.2 & $(0.7)$ \\
\hline & warm & light & 1 & $(1.4)$ & 0 & $(0.2)$ & 3.5 & $(0.7)$ \\
\hline \multirow{6}{*}{$\begin{array}{c}7 \\
\text { months }\end{array}$} & ambient & heavy & 0 & $(0.3)$ & 0 & $(0.1)$ & 2.5 & $(0.3)$ \\
\hline & ambient & standard & 10 & (14.0) & 2 & (2.9) & 3.2 & $(0.3)$ \\
\hline & ambient & light & 39 & $(8.0)$ & 9 & (1.5) & 3.1 & $(0.2)$ \\
\hline & warm & heavy & 0 & $(0.3)$ & 0 & $(0.1)$ & 2.9 & $(0.6)$ \\
\hline & warm & standard & 4 & (8.0) & 1 & $(1.2)$ & 4.2 & $(0.7)$ \\
\hline & warm & light & 22 & (5.2) & 4 & $(1.2)$ & 3.5 & $(0.7)$ \\
\hline
\end{tabular}

\subsection{Crop load experiments}

The core browning data from the crop load experiment in 2016/17 are shown in the boxplot (Fig. 6A) for the binary groups high and low severity and the corresponding ROC plot is given in Fig. 6B. All available samples $(N=54)$ were classed as either high or low severity. The ROC curve analysis shows very good utility for crop load as a predictor of disorder risk with an AUC of $85.2 \%$ (95\% Cls from 75.2-95.2\%) and an optimal threshold of $89 \%$ of a full crop load ( $\mathrm{x}, \mathrm{y}$, coordinates of $12 \%$ false positive percentage, $66 \%$ true positive percentage shown as a point on the ROC curve) to separate the high and low severity groups. 
In 2017/18, heavy crop load treatments (nested within the temperature cell division treatment plots) at the KOB reduced the mean incidence (severity) of core browning to $17 \%$ (4) compared to the standard or light levels with $37 \%$ (11) or $64 \%$ (23), respectively. The utility of crop load as a binary predictor of core browning was confirmed with an AUC value of $71.8 \%$ at the KOB and at the Kippenhausen orchard with a slightly lower AUC value of 61.0 $\%$ (ROC plots not presented). One possible explanation for the lower AUC value at the Kippenhausen orchard is the late timing of hand thinning some 5 weeks prior to harvest compared to the KOB where final crop loads were established earlier after June drop. However, the optimal threshold levels calculated from the ROC curves were the same for both the KOB and Kippenhausen with $59 \%$ and $58 \%$ of a full crop load as a binary predictor to separate the high and no / low incidence classes.

In 2018/19, the clear protective effect of crop load treatments nested within the temperature preharvest treatments to reduce the incidence and severity of core browning can be seen in Table 5. At the first storage removal, fruit from the ambient heavy and standard treatments show either no or a very low core browning. The ambient light crop load treatment shows a higher but still relatively low incidence (severity) of $13 \%$ (2). At the second storage removal core browning in all treatments is higher overall but the disorder pattern is similar to the first removal with a clear influence of crop load. Heavy crop loads are totally protective and show very low (no) symptoms.

As other reviewers have noted, the effects of crop load on postharvest behaviour of apple in regard to gas exchange disorders, remain largely unexplained (Ferguson et al., 1999; Wünsche and Ferguson, 2005). With the exception of calcium physiology there is very little relevant literature to help link crop load effects on postharvest behaviour. We can find only two papers that are partially relevant, both deal with carbohydrate metabolism and do not address other aspects that could affect gas exchange within the fruit such as skin characteristics, cell size, number or intercellular structure. Klages et al. (2001) could explain fruit size differences in 'Braeburn' apple between high and light crop load trees based on differences in the carbohydrate supply from the leaves or within high crop load trees by sink activity and Palmer et al. (2013) studied the crop load effects of 'Scifresh' apples on carbohydrate accumulation. However, neither of these two studies included any postharvest assessments.

In all study years, the heavy crop load treatments consistently reduced core browning when compared to standard or light treatments and our initial hypothesis that the protective effect of crop load could be maintained when preharvest temperatures varied was confirmed. 

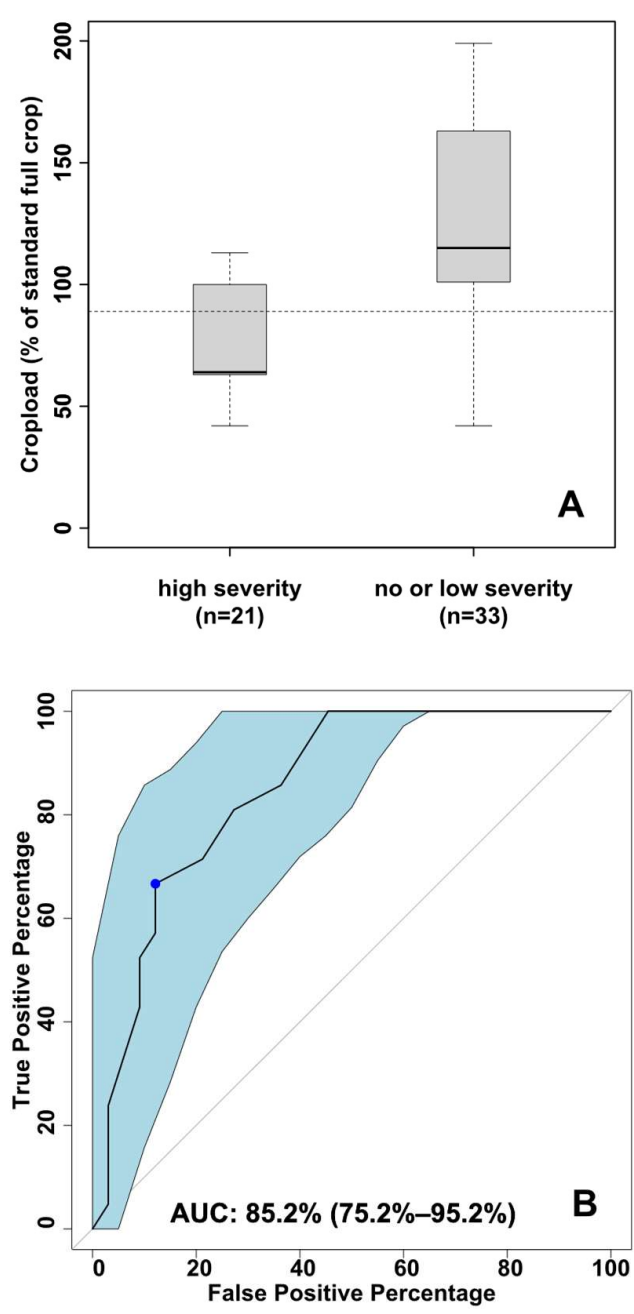

Fig. 6. A) Boxplot of core browning severity in 'Braeburn' apples in 2016/17 at the KOB after five months CA storage versus crop load as a \% of a standard full crop (100\%). Optimal threshold from the receiver operating characteristic (ROC) curve of $89 \%$ shown as the dotted horizontal line. B) ROC curve for crop load to predict core browning severity. Shaded area is the $95 \% \mathrm{Cl}$ for the ROC curve. Number of samples $=54$.. 


\section{CONCLUSIONS}

In each study year, the cell division temperature treatments effectively produced three distinct populations of fruit each with different size profiles and growths rates and presumably these apples all had a range of different internal tissue structures / porosity at-harvest. However, the field data we were able to collect over the three seasons does not support a strong effect (if any) of post bloom temperatures ( $\triangle$ of $+/-2{ }^{\circ} \mathrm{C}$ from ambient) during cell division on internal browning incidence in 'Braeburn' apples. In contrast, preharvest temperature conditions of $>10^{\circ} \mathrm{C}$ during the last 4 weeks preharvest can markedly influence the development of internal browning. Further studies are necessary in the preharvest period to try and untangle the effects of temperature on carbohydrate uploading into the fruit, fruit growth and expansion (ideally including non-destructive determination of porosity) and to explore these processes in relation to the stage and rate of fruit maturation and ripening. In all study years, the high crop load treatments consistently reduced core browning when compared to standard or light treatments. How crop load affects postharvest browning behaviour is not as yet clearly explained.

ROC curve analyses are a useful methodology to form stronger links between preharvest factors and the postharvest behaviour of fruit. The crop load carried by the tree, the timing of thinning operations in relation to fruit development together with the decision of when to harvest the apples are factors under grower control that can be managed to help reduce disorders in CA storage. In addition, a better understanding of the preharvest temperature effects on browning susceptibility has the potential to allow the duration of CA stored 'Braeburn' to be optimised.

\section{ACKNOWLEDGEMENTS}

The 'BigApple' project was supported by funds of the Federal Ministry of Food and Agriculture (BMEL) based on a decision of the Parliament of the Federal Republic of Germany via the Federal Office for Agriculture and Food (BLE) under the innovation support programme. We gratefully acknowledge our 'BigApple' project partners who all contributed to the successful completion of this project. We thank Paul Figel Refrigeration for technical assistance with the cooling machines and temperature controllers in the orchard, Erich Röhrenbach and the Marktgemeinschaft Bodenseeobst (MaBo) for access to the orchard at Kippenhausen and our KOB work colleagues for help in the field and lab and all the students who undertook internships at the KOB over this time.

\section{CRediT roles:}

R.J. McCormick : Investigation, Methodology, Project administration, Data analysis and Writing - original draft, Visualization. K. Biegert : Investigation, Methodology, Data curation, Writing review editing, Data analysis. J. Streif : Conceptualisation, Investigation, Methodology, Review editing.

\section{Literature cited}

Dražeta, L., Lang, A., Hall, A., Volz, R., Jameson, P., 2004. Air volume measurement of 'Braeburn' apple fruit. Journal of Experimental Botany 55, 1061-1069. doi:10.1093/jxb/erh118.

Elgar, H., Lallu, N., Watkins, C., 1999. Harvest date and crop load effects on a carbon dioxide-related storage injury of 'Braeburn' apple. HortScience 34, 305-309. doi:10.21273/hortsci.34.2.305.

Ferguson, I., Volz, R., Woolf, A., 1999. Preharvest factors affecting physiological disorders of fruit. Postharvest Biology and Technology 15, 255-262. doi:10.1016/s09255214(98)00089-1.

Herremans, E., Verboven, P., Bongaers, E., Estrade, P., Verlinden, B., Wevers, M., Hertog, M., Nicolai, B., 2013. Characterisation of 'Braeburn' browning disorder by means of Xray micro-CT. Postharvest Biology and Technology 75, 114-124. doi:10.1016/j.postharvbio.2012.08.008. 
Herremans, E., Verboven, P., Defraeye, T., Rogge, S., Ho, Q., Hertog, M., Verlinden, B., Bongaers, E., Wevers, M., Nicolai, B., 2014. X-ray CT for quantitative food microstructure engineering: The apple case. Nuclear Instruments and Methods in Physics Research Section B: Beam Interactions with Materials and Atoms 324, 88-94. doi:10.1016/j.nimb.2013.07.035.

Hirst, P., 2016. private communication.

Janssen, S., Verboven, P., Nugraha, B., Wang, Z., Boone, M., Josipovic, I., Nicolaï, B., 2020. $3 d$ pore structure analysis of intact 'Braeburn' apples using $x$-ray micro-CT.

Postharvest Biology and Technology 159, 111014. doi:10.1016/j.postharvbio.2019.111014.

Johnston, J., 2018. private communication.

Klages, K., Donnison, H., Wünsche, J., Boldingh, H., 2001. Diurnal changes in non-structural carbohydrates in leaves, phloem exudate and fruit in 'Braeburn' apple. Functional Plant Biology 28, 131-139. doi:10.1071/pp00077.

Lang, A., 1990. Xylem, phloem and transpiration flows in developing apple fruits. Journal of Experimental Botany 41, 645-651. doi.org/10.1093/jxb/41.6.645.

Lau, O., 1998. Effect of growing season, harvest maturity, waxing, low $\mathrm{O}_{2}$ and elevated $\mathrm{CO} 2$ on flesh browning disorders in 'Braeburn' apples. Postharvest Biology and Technology 14, 131-141. doi:10.1016/s0925-5214(98)00035-0.

Leisso, R., Hanrahan, I., Mattheis, J., 2019. Assessing preharvest field temperature and atharvest fruit quality for prediction of soft scald risk of 'Honeycrisp' apple fruit during cold storage. HortScience 54, 910-915. doi.org/10.21273/HORTSCI13558-18.

Little, C., Holmes, R., 2000. Storage technology for apple and pears: A guide to production postharvest treatment and storage of pome fruit in Australia. Department of Natural Resources and Environment, Victoria, Australia.

Malladi, A., 2020. Molecular physiology of fruit growth in apple. Horticultural Reviews 47, 142. doi:10.1002/9781119625407.ch1.

Mellidou, I., Buts, K., Hatoum, D., Ho, Q., Johnston, J., Watkins, C., Schaffer, R., Gapper, N., Giovannoni, J., Rudell, D., Hertog, M., Nicolai, B.M., 2014. Transcriptomic events associated with internal browning of apple during postharvest storage. BMC Plant Biology 14, 328-344. doi:10.1186/s12870-014-0328-x.

Osinenko, P., Biegert, K., McCormick, R., Göhrt, T., Devadze, G., Streif, J., Streif, S., 2021. Application of non-destructive sensors and big-data analysis to predict physiological storage disorders and fruit firmness in 'Braeburn' apples. Submitted to Journal of Computers Electronics and Agriculture.

Palmer, J., Diack, R., Johnston, J., Boldingh, H., 2013. Manipulation of fruit dry matter accumulation and fruit size in 'Scifresh' apple through alteration of the carbon supply, and its relationship with apoplastic sugar composition. The Journal of Horticultural Science and Biotechnology 88, 483-489. doi.org/10.1080/14620316.2013.11512995.

Rabus, C., Streif, J., 2000. Effect of various preharvest treatments on the development of internal browning in 'Braeburn' apples. Acta Horticulturae 518, 151-157. doi.org/10.17660/actahortic.2000.518.20.

Rajapakse, N., Banks, N., Hewett, E., Cleland, D., 1990. Development of oxygen concentration gradients in flesh tissues of bulky plant organs. Journal of the American Society for Horticultural Science 115, 793-797. doi:10.21273/jashs.115.5.793.

Robin, X., Turck, N., Hainard, A., Tiberti, N., Lisacek, F., Sanchez, J., Müller, M., 2011. pROC: an open-source package for R and $\mathrm{S}+$ to analyze and compare ROC curves. BMC Bioinformatics 12, 77. doi.org/10.1186/1471-2105-12-77.

Rudell, D., Leisso, R., Mattheis, J., Giovannoni, J., Gapper, N., Nicolai, B., Watkins, C., Johnston, J., Hertog, M., Schaffer, R., 2017. Gene expression monitoring for risk assessment of apple and pear fruit storage stress and physiological disorders. URL: http://www.freepatentsonline.com/y2017/0260586.html. US Patent Application No. US20170260586(A1).

Ruess, F., Stösser, R., 1993. Untersuchungen über das interzellularsystem bei apfelfrüchten mit methoden der digitalen bildverarbeitung. Gartenbauwissenschaft 58, 197-205. 
Saquet, A., Streif, J., Bangerth, F., 2003. Reducing internal browning disorders in 'Braeburn' apples by delayed controlled atmosphere storage and some related physiological and biochemical changes. Acta Horticulturae 628, 453-458. doi:10.17660/actahortic.2003.628.57.

Smith, R., Lougheed, E., Franklin, E., McMillan, I., 1979. The starch iodine test for determining stage of maturation in apples. Canadian Journal of Plant Science 59, 725735. doi:10.4141/cjps79-113.

Sperling, O., Silva, L., Tixier, A., Theroux-Rancourt, G., Zwieniecki, M., 2017. Temperature gradients assist carbohydrate allocation within trees. Scientific Reports 7, 1-10. doi:10.1038/s41598-017-03608-w.

Streif, J., Kittemann, D., 2018. Fruchtqualität, Ernte und Lagerung, in: Büchele, M. (Ed.), Lucas' Anleitung zum Obstbau. Verlag Eugen Ulmer, Stuttgart, DE. chapter 14, pp. 393-435.

Toivonen, P., 2019. Relation between preharvest conditions, harvest maturity and postharvest performance of apples. Acta Horticulturae 1256, 469-480. doi:10.17660/actahortic.2019.1256.67.

Volz, R., Oliver, M., Legg, S., Stanley, J., Morgan, C., Bradley, A., Pidakala, P., 2000. Prediction of BBD (HR99P11.05). Technical Report No 2001/160. HortResearch report to ENZA (NZ) International. $21 \mathrm{pp}$.

Walsh, K., McGlone, V., Han, D., 2020. The uses of near infra-red spectroscopy in postharvest decision support: A review. Postharvest Biology and Technology 163, 111139. doi.org/10.1016/j. postharvbio.2020.111139.

Warrington, I., Fulton, T., Halligan, E., De Silva, H., 1999. Apple fruit growth and maturity are affected by early season temperatures. Journal of the American Society for Horticultural Science 124, 468-477. doi.org/10.21273/jashs.124.5.468.

Watkins, C., Mattheis, J., 2019. Apple, in: de Freitas, S.T., Pareek, S. (Eds.), Postharvest physiological disorders in fruits and vegetables. CRC Press, Boca Raton, FL, USA. chapter 8, pp. 165-206. doi.org/10.1201/b22001

Wünsche, J., Ferguson, I., 2005. Crop load interactions in apple. Horticultural Reviews 31, 231-290. doi:10.1002/9780470650882.ch5.

Zhang, L.Y., Peng, Y.B., Pelleschi-Travier, S., Fan, Y., Lu, Y.F., Lu, Y.M., Gao, X.P., Shen, Y., Delrot, S., Zhang, D.P., 2004. Evidence for apoplasmic phloem unloading in developing apple fruit. Plant Physiology 135, 574-586. doi:10.1104/pp.103.036632. 